\title{
A AEMULATIO SENEQUIANA: O CASO DA TRAGÉDIA AGAMEMMNON
}

\author{
Marco Aurélio Rodrigues*
}

Recebido em: 16/07/2018

Aprovado em: 26/11/2019

RESUMO: Apresentado em 458 a.C, o drama esquiliano Agamêmnon faz parte da trilogia Oresteia, obra aclamada em toda a Antiguidade e que serviu de parâmetro para muitos autores posteriores. Já a tragédia homônima de Sêneca foi escrita entre os anos de 40 e 65 d.C., e chegou até a modernidade com intrigantes questões de composição. O presente artigo dedica-se a analisar algumas passagens que correspondem a um diálogo direto entre a tradição grega e a romana a partir do conceito de emulação (aemulatio). Para os críticos antigos, não bastava que o autor realizasse a imitação (imitatio) de uma obra. O literato deveria tentar se igualar a seu predecessor. Dessa forma, embora muitos estudiosos questionem as fontes de inspiração do autor romano e outros refutem ter Sêneca emulado a tragédia de Ésquilo, pretende-se mostrar que há inúmeros elementos que merecem atenção e que aproximam os dois dramas.

PALAVRAS-CHAVE: Agamêmnon; tragédia; Ésquilo; Sêneca; aemulatio.

\section{THE SENECAN AEMULATIO: THE CASE OF THE TRAGEDY AGAMEMNON}

* Professor Adjunto, curso de Licenciatura em Letras-Português, Campus Santana, Universidade Federal do Amapá. 
try to equal his predecessor. Therefore, although many scholars question the Roman author's sources of inspiration and others refute that Seneca emulated the tragedy of Aeschylus, we intend to show that there are countless elements worth of attention and that connect both dramas.

KEYWORDS: Agamemnon; tragedy; Aeschylus; Seneca; aemulatio.

\section{INTRODUÇÃO}

possibilidade de analisar uma produção de Ésquilo datada de 458 a.C. ${ }^{1}$ junto
com a tragédia de Lúcio Aneu Sêneca escrita entre 40 a 65 d.C., ${ }^{2}$ comparando
os elementos que as tornam grandes clássicos da Literatura mundial e olhando para suas similitudes e discrepâncias, é de grande valia para entender os movimentos que fazem com que essas obras não vejam esgotadas as suas possibilidades de interpretações, por melhores e mais amplos que sejam os estudos dedicados a elas. A permanência em ambas de uma estrutura que remonta às análises de Aristóteles, elaboradas por volta de 320 a.C., demonstra o quanto o gênero dramático tem uma fórmula aclamada ao longo dos séculos. Mesmo quando inovações são aplicadas e novas formas de conceber o drama passam a vigorar, não é possível desvinculá-las do modus operandi básico proposto na Antiguidade. Dessa forma, os romanos parecem conceber o teatro de forma semelhante ao modelo grego, ${ }^{3}$ em muitos casos apenas modificando o mito ou transformando a ação de um pensamento que se alinhasse com mais clareza às necessidades da urbe. Se por um lado Aristóteles (Poética, 1449b24-28), analisando as tragédias gregas, fala sobre a imitação $(\mu i ́ \mu \eta \sigma \iota \varsigma)$ como o princípio que define o valor dedicado à encenação, Marco Túlio Cícero, em 45 a.C., retomará a questão (Cic. Tusc. 4.8) e, em sua definição, aliará o conceito de imitatio ao de aemulatio. Assim sendo, a cultura romana retomará os elementos que eram caros ao universo literário grego e os aprimorará, da mesma forma que também desenvolverá novos gêneros, em uma cultura que legou ao mundo ocidental as bases de uma tradição que perdura há mais de dois mil anos.

De acordo com Martins (2009, p. 25), os gêneros só evoluíram porque os romanos entendiam a classificação aristotélica e respeitavam as mais diversas divisões, aprimorando as classes literárias de acordo com os próprios grupos aos quais pertenciam.

\footnotetext{
${ }^{1}$ A data para Agamêmnon, de Ésquilo, acompanha a informação transmitida por Page (1972).

${ }^{2}$ A data para Agamêmnon, de Sêneca, acompanha a informação transmitida por Zwierlein (1999).

${ }^{3}$ A esse respeito, é interessante o trabalho de Erasmo (2004), no qual o autor discute exatamente a ideia amplamente aceita no século XX, de Beare (1964), de que a tragédia senequiana estaria ligada à tragédia grega. Para Erasmo (2004, p. XI), a tragédia romana desenvolve uma teatralidade própria, em um estilo que remonta particularmente a cultura romana.
} 
Assim, se a imitatio torna-se uma forma de retomar a produção dos predecessores, apenas imitá-los não era o bastante. Era preciso igualar o trabalho em uma espécie de homenagem e prova da competência do autor: a esse processo dá-se o nome de aemulatio. Dessa forma, imitatio e aemulatio tornam-se fórmulas para os autores latinos. Sobre o assunto discorre Martins (2009, p. 27):

Esses processos semelhantes de composição é que permitiam ao público discernir se um poeta e/ou um prosador era melhor do que outro e se um autor tinha se valido adequadamente dos mecanismos e processos de composição, a que se deu o nome de ars (arte), isto é, aferir seu ingenium, sua habilidade técnica inata.

Assim, se não é preciso provar à modernidade o ingenium de autores como Sêneca, visto que a própria tradição reconheceu a arte do poeta, cabe ao estudioso demonstrar quais elementos colocam Sêneca em tal posição, bem como de que forma, no caso deste trabalho, a aemulatio (emulação) da obra esquiliana torna-se evidente no drama do autor latino.

\section{SÊNECA, EURÍPIDES, ÉsQUILO}

Quando Sêneca compôs seu Agamêmnon, Ésquilo já estava morto há quase meio milênio. No entanto, graças à trajetória percorrida pelo texto literário na Antiguidade, os romanos tiveram acesso às obras trágicas dos gregos, e é certo que Sêneca teve ao menos algum contato com a trilogia esquiliana para a composição de seu Agamêmnon.

Ainda assim, a questão das fontes de inspiração das tragédias de Sêneca é controversa. Entre os especialistas, não há consenso sobre as semelhanças entre o Agamêmnon latino e o texto de seu predecessor helênico. Aliás, é muito provável que Sêneca não tivesse apenas a obra de Ésquilo como fonte, já que tragédias como Electra, de Sófocles, Ifigênia em Áulis, de Eurípides, e outros sete dramas do mesmo período também fizeram uso da mesma temática mítica. Ainda assim, é preciso notar que, mesmo que muitos estudiosos defendam ter sido Eurípides o autor que inspirou o tragediógrafo latino, ${ }^{4}$ não se devem esquecer as palavras de Aélion (1983, p. 399), para quem as peças de Eurípides estão diretamente relacionadas à obra de Ésquilo:

Ele [Eurípides] é o herdeiro de Ésquilo, porque, como ele, quis utilizar os velhos mitos como fonte de reflexão sobre a condição humana. Nossas análises mostraram, é verdade, que sua reflexão se desenvolve em uma direção diferente da de Ésquilo. Eurípides não é o poeta de uma verdade, ele não chega a encontrar o que dá sentido à vida humana. Mas ele não se resigna a permanecer na ignorância e na escuridão. ${ }^{5}$

\footnotetext{
${ }^{4}$ Vide Star (2017).

${ }^{5}$ As traduções presentes no artigo, exceto quando devidamente referenciadas, são de minha autoria.
} 
Portanto, mesmo que parte da tradição coloque Eurípides como a fonte de inspiração para os autores latinos, as tragédias dos dois helenos acabam por dialogar em alguma instância e, assim, o drama esquiliano estaria em todo caso próximo da obra de Sêneca.

\section{A tragédia Agamêmnon de Ésquilo}

Agamêmnon - que junto com as peças Coéforas e Eumênides forma a trilogia conhecida como Oresteia -, foi apresentada em 458 a.C., tendo ganhado o primeiro prêmio do festival e o último da carreira de Ésquilo, que veio a falecer em 456 a.C. É na tragédia sobre a vida do rei argivo e grande vencedor de Troia que se pode ter a certeza do vínculo que Ésquilo mantinha com a tradição. Trata-se da tragédia em que o homem mais se submete ao acaso, impossibilitado de agir em causa própria, pois sua mácula advém de um espaço e tempo anteriores a sua própria existência.

A tragédia de Ésquilo começa com um vigia desolado que espera notícias do fim da guerra de Troia. Quando recebe o alerta e o comunica ao restante do palácio, o coro passa, então, a se manifestar sobre os acontecimentos anteriores e a guerra que durou dez anos. As palavras do coro lembram que o poder supremo de Zeus é o responsável pelo controle da imperfeição humana e pela aprendizagem que lhe é imposta (Ag. v. 174-5). Através das palavras dos cidadãos, é expressa uma lição que marca de forma crucial toda a Oresteia, pois

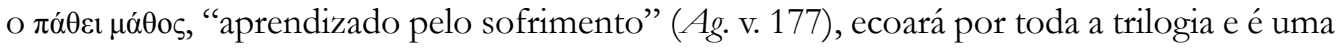
das chaves essenciais para a compreensão de toda a saga dos Atridas.

Em seguida, aparece Clitemnestra e, através de um interessante diálogo do coro, é possível perceber que a rainha não demonstra aos cidadãos suas intenções. Trata-se de uma rainha comovida com o retorno do marido, apreensiva pelas resoluções da guerra, ao mesmo tempo em que apresenta uma frieza no trato com os anciãos, aspecto que aponta para uma insegurança pelos acontecimentos do porvir.

Assim, até que o arauto entre em cena ( $A g$. v. 503), o coro e Clitemnestra intercalam uma ode justificando os motivos que levaram à derrocada de Troia. Por isso, entidades como Zeus e as Erínias são citadas como aquelas que levam a Justiça para Ílio. O que pode ser compreendido até mesmo como uma ironia, visto que a peça recordará o tempo todo a Justiça de Zeus e a necessidade de purificação familiar. Além disso, as Erínias são as entidades que rodeiam os Atridas há tempos e cobrarão os assassinatos consanguíneos.

$\mathrm{O}$ arauto narra sua própria experiência como aquele que é o transmissor de mau agouro, pois é o emissário das notícias ruins sobre as calamidades que atingem os homens. O mensageiro nesse passo ganha destaque e, de fato, cumpre um papel que se tornaria comum na tragédia grega: o de portador das notícias que geram um revés na trama, pois a ele cabe trazer à cena mensagens que, ou por convenção não poderiam ser mostradas ao público (mortes, por exemplo) ou, ainda, constituem relatos passados e de guerra. A fala do mensageiro desperta também um lado sombrio acerca da vitória dos gregos contra os troianos. Em consequência, o segundo estásimo começa com uma rememoração por parte do coro da história de Páris e Helena. É a partir do verso 810 que Agamêmnon aparece em 
cena. O comandante argivo fala sobre a vitória e sobre o comedimento que é próprio do rei vencedor, principalmente daquele que havia aprendido lições valiosas com as intrigas ao longo da guerra de Troia. A partir deste ponto, um diálogo com Clitemnestra demonstra uma cumplicidade entre o casal que somente reforça o caráter perverso da mulher de Agamêmnon que, inclusive, parece benévola com a concubina do marido, a profetisa Cassandra.

Cassandra, antes de entrar no palácio, pressente seu destino e clama pelo auxílio de Apolo. Sendo assim, ela apontará os erros cometidos na casa dos Atridas, pois a chegada de Agamêmnon apenas encobria uma falsa comemoração de vitória, fato que deixa os anciãos assustados e receosos com os próximos acontecimentos.

As palavras de Cassandra precedem e aumentam a expectativa do que esperava por Agamêmnon dentro do palácio. Quando aceita sua condição e seu destino, a profetisa de Apolo também se entrega à morte e logo se ouvem os lamentos do rei. Ao sair do palácio, Clitemnestra já argumenta sobre seus atos, a justiça realizada em nome de Ifigênia e as entidades que a protegem por seu feito.

Egisto, por fim, aparece nos momentos finais da tragédia e seu discurso também é repleto de argumentos que justificam uma justiça antiga, uma reparação por atos cometidos pelo pai de Agamêmnon. Vale observar que as palavras de Clitemnestra nos momentos finais

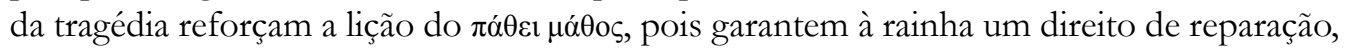
justificando que o rei tinha apenas recebido a lição pelos atos errôneos cometidos ao longo da vida.

\section{A tragédia Agamêmnon de Sêneca}

De data incerta, acredita-se que Agamêmnon, de Sêneca, tenha sido escrita entre os anos 40 a 65 d.C. A tragédia também lida com os acontecimentos que antecedem o retorno do rei argivo à casa. Trata-se de um drama que, com uma configuração diferente daquela dada por Ésquilo, recria com maestria os momentos finais do vitorioso comandante argivo, aliando uma história tradicional a um novo pensamento vigente em Roma. A esse respeito, como pontua Vieira (2008, p. 157), por mais que as tragédias tenham sido uma forma de experimentação do prosador Sêneca, elas são expressões de um conteúdo literário vigoroso da época do principado de Nero.

A tragédia, logo no prólogo, apresenta o espectro de Tiestes, pai de Egisto, que recorda a maldição que recai sobre a família dos Atridas, inclusive retrata a figura de Agamêmnon, rex ille regum "o famoso rei dos reis" (Sen. Ag. v. 39), anunciando sua chegada e a morte planejada por Clitemnestra. O coro de argivas, em seguida, aponta para os crimes que são cometidos no palácio e a incerteza dos próximos acontecimentos.

No segundo ato, em um diálogo tenso entre Clitemnestra e a ama, a rainha fala explicitamente dos seus planos de assassinato e é aconselhada pela criada a desistir de seus objetivos. Não tarda a aparecer Egisto e insistir para que a rainha siga com seu projeto. $\mathrm{O}$ diálogo entre Egisto e Clitemnestra introduz um paralelo interessante e reforça o monólogo inicial de Tiestes: 
O emprego desses paralelos no campo da elocução, gerando um eco das palavras de Tiestes nos dois monólogos de entrada, que abrem as duas cenas justapostas do segundo ato, produz efeito que sugere não a ocorrência de um mero desdobramento de cada personagem falando consigo mesma, porém, algo como uma sobreposição de personagens, ou seja, nessas palavras de Clitemnestra e Egisto, por efeito da relação intratextual, manifesta-se a presença do próprio Tiestes. (Lohner, 2009, p. 128)

Embora as palavras de Egisto reforcem o desejo de vingança de Tiestes, Clitemnestra ainda demonstra receio em concretizar o assassinato do próprio marido. Essa indecisão reforça o estoicismo ${ }^{6}$ de Sêneca, pois não se trata de uma mulher que tem medo de concretizar um ato, mas que reflete sobre as consequências dele. Assim, no terceiro ato, o encontro da rainha com o mensageiro Euríbates, que narra os acontecimentos da guerra e o retorno de Agamêmnon, reforça ainda mais um discurso que tende a promover a grandiloquência do rei e a morte de muitos heróis e, dessa forma, aumenta a dúvida da consorte em relação a seu objetivo.

A tradição ${ }^{7}$ costuma apontar a figura de Clitemnestra em Sêneca como potencialmente menor que aquela de Ésquilo. Trata-se de uma rainha que titubeia com frequência em seu objetivo. Todavia, é preciso analisar a figura de Clitemnestra com cautela: embora ela passe a maior parte do drama em dúvida sobre seu ato, o modo com o qual Sêneca desenha o caráter dessa personagem denuncia a crescente de uma figura feminina que assume a responsabilidade pela morte do marido e, depois de concretizado o ato, tende a ir até as últimas consequências.

Cassandra, a profetisa e agora concubina do rei, trazida de Troia, entra acompanhada do coro de argivas e, em um estado de transe, prevê a morte de Agamêmnon, em um discurso repleto de metáforas que evocam o mundo animal. ${ }^{8}$ Após o transe da profetisa, Agamêmnon entra no palácio e Cassandra tenta alertá-lo sobre os planos da esposa. O quarto ato termina

\footnotetext{
${ }^{6}$ De acordo com Veyne (2003, p. 32), a filosofia estoica se estabeleceu trezentos anos antes de Sêneca, dando continuidade a duas grandes ideias do pensamento grego: a questão da felicidade e o ideal do homem sábio. Para Sêneca, uma das grandes questões que envolve a busca da felicidade está intimamente ligada à moralidade. Assim, o homem sábio possui as qualidades de bom pai, bom esposo, bom cidadão e esses aspectos são tão importantes quanto uma busca pessoal pelo bom ou mau bem-estar. Sobre o estoicismo de Sêneca, é salutar, ainda, mencionar as palavras de Star (2017, p. 546), para quem o dramaturgo latino argumenta que as paixões devem ser erradicadas da alma humana e que o mundo é guiado pela benevolente providência divina.

${ }^{7}$ Para uma melhor apreciação do assunto, vide Serrano (1981).

${ }^{8}$ As metáforas são marcas contundentes da tragédia esquiliana. Como bem pontua Moreau (1985, p. 8), o uso da linguagem metafórica em Ésquilo potencializa a imagem mítica, dando maior vivacidade à própria ação do espetáculo. No caso das palavras de Cassandra, as metáforas do mundo animal, tanto em Ésquilo quanto em Sêneca, reforçam uma ideia de primitividade relacionada à violência e ao assassínio.
} 
com o coro de mulheres argivas rememorando os feitos de Agamêmnon e as perdas sofridas pelo palácio dos Atridas ao longo do tempo.

No quinto ato, Cassandra descreve a morte de Agamêmnon e, imediatamente, Electra pede a Estrófio que leve seu irmão Orestes para longe do palácio. A rainha Clitemnestra, determinada em seu plano, agora promete vingança contra a própria filha e a ameaça de morte. No entanto, Egisto, ao perceber que a morte não amedronta Electra, convence a rainha a aprisioná-la e a tratá-la como escrava em seu próprio lar. Por fim, Clitemnestra condena Cassandra e assim termina a peça.

\section{A aemulatio SEnequiana}

Um estudioso do texto literário, principalmente quando pertencente a uma tradição muito distante, como acontece no âmbito dos Estudos Clássicos, depara-se sempre com a questão da "intenção" do autor. Ao falar em aemulatio, é necessário que o estudioso realize uma pesquisa comparada entre obras e, provavelmente, incorra no erro de realizar especulações dedutivas sobre os objetos de estudo. Acerca da "intenção", Compagnon (2006, p. 53) ressalta o dualismo existente nos estudos modernos entre o pensamento e a linguagem e, por mais que exista a crítica para o estudo de uma suposta "intenção do autor", o problema não parece ter sido resolvido.

Desde a Antiguidade, a questão da “intenção do autor”" esteve intimamente ligada aos modos de composição. A cultura romana, herdeira de uma tradição helênica, tratou desde o início de refletir acerca dos modelos e gêneros, procurando ampliar a reflexão iniciada por seus antecessores. Assim, termos como voluntas, actio, imitatio, aemulatio, comparatio, fides, vertere, interpres ${ }^{9}$ etc. pertencem a um grupo de conceitos utilizados pelos latinos para discutir os mais variados aspectos da composição literária.

Quando Cícero descreve a "emulação" em Discussões Tusculanas, o orador pretende apontar a origem do conceito e justificá-lo dentro do universo da composição literária. Assim, ele explica:

aemulatio autem dupliciter illa quidem dicitur, ut et in laude et in vitio nomen hoc sit; nam et imitatio virtutis aemulatio dicitur - sed ea nihil hoc loco utimur; est enim laudis -, et est aemulatio aegritudo, si eo quod concupierit alius potiatur, ipse careat. (Cic. Tusc. IV.8)

Contudo, o que se chama emulação tem duplo sentido: esse termo se aplica tanto a um mérito quanto a uma falha; uma vez que também a imitação da virtude é chamada emulação - mas dessa não se ocupa: ela é louvável -, e a emulação nociva, que é sentida por alguém que almeja algo obtido por outro.

\footnotetext{
${ }^{9}$ Embora esses conceitos pertençam a campos semânticos que se comuniquem, mas que não são exatamente os mesmos, convém uma análise pormenorizada de cada um deles para compreender suas especificidades de aplicação. Assim, as noções citadas são apresentadas e esmiuçadas em diversos trabalhos, como os de Achcar (1994), Furlan (2001), Vieira (2006) e Martins (2009).
} 
De acordo com Cícero, trata-se de uma forma de o autor, ao retomar obras célebres, homenagear seu predecessor, obviamente inserindo seu próprio estilo e pensamento, mas nunca deixando de lado a essência visitada na obra de partida. No entanto, é importante lembrar que o cuidado que os autores têm em falar sobre o conceito está intimamente ligado

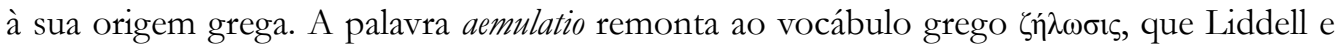

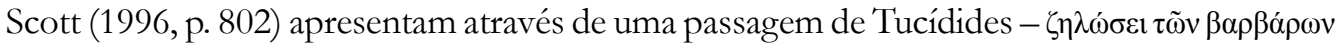
(Th. I.132), "emulará dos bárbaros" -, em que o sentido se refere ao ato de imitar aspectos da tradição bárbara que sejam benéficos aos próprios gregos. Essa definição, no entanto, não é a única, tendo a palavra, por extensão de significado, um sentido negativo ligado à "inveja", "maledicência" (emulação nociva), que também chegou aos romanos. Tal significado é atestado, por exemplo, no Oxford Dictionary of Latin (1985, p. 64), que refere a passagem de Discussões Tusculanas (I.43), de Cícero, na qual o autor escreve:

[...] quod iis aemulemur, qui ea habeant quae nos habere cupiamus, profecto beati erimus, cum corporibus relictis et cupiditatum et aemulationum erimus expertes; $[\ldots]$.

[...] porque emularíamos aqueles que tenham aquilo que nós desejamos, seguramente seríamos felizes, quando, após abandonarmos nossos corpos, estivermos livres tanto do desejo quanto da emulação; [...].

A passagem presente no dicionário remete à citação de Cícero que discute o sentido negativo do termo. Assim, acompanhando o primeiro significado grego, para os latinos a palavra também poderia representar uma unfriendly rivalry, "rivalidade hostil". Dessa forma, pode-se compreender o motivo de os pensadores clássicos sempre enfatizarem o lugar de uso e o sentido assumido por aemulatio no âmbito da discussão literária. Sobre esse tema, é importante lembrar as palavras de Quintiliano (Quint. X.II.4: "ante omnia igitur imitatio per se ipsa non sufficit" / "a própria imitação, pois, antes de tudo, por si só não é suficiente”), para quem a emulação se torna fundamental, pois não bastava a um autor apenas realizar uma imitação (imitatio), visto que tal ação não contempla a construção de uma nova obra literária.

Assim, como bem acrescenta Achcar (1994, p. 29), imitar um antecessor não basta na tessitura literária, mas é preciso que ocorra a emulação, ao menos a tentativa de igualar seu predecessor, pois tal ato "corresponde a uma exigência de originalidade". Portanto, a emulação torna-se uma necessidade para uma composição elevada. Agora, definida a importância da aemulatio e sua função na criação literária, outra questão apresenta-se: a comparação entre as obras. Nessa linha de raciocínio, mesmo que autores no início do século XX não negassem a influência de Ésquilo na obra de Sêneca, indicando inclusive uma "influência clara de Ésquilo" (Tarrant,1976, p. 10), por outro lado, Hermann (1924, p. 324), dentre eles, ressalta que conhecer o texto de Sêneca não pressupõe o conhecimento do drama helênico:

As únicas partes das peças de Ésquilo que encontram um paralelo em Sêneca são a chegada de um arauto com a notícia das tempestades e uma cena em que Cassandra prenuncia o assassinato de Agamêmnon 
e de si mesma; mesmo aqui a similaridade da situação é pesadamente superada pela diversidade de conteúdo e tratamento. Nada na peça de Sêneca requer conhecimento direto de Ésquilo.

Corroborando a posição de Hermann e realizando um exaustivo estudo acerca das fontes, Cardoso (2005, p. 44) conclui que elas foram as mais diversas, sem deixar a tragédia ática de lado, mas, claramente, imprimindo em seus textos uma originalidade que se tornaria própria do autor romano.

Com efeito, a organização estrutural da tragédia de Sêneca difere consideravelmente da obra de Ésquilo. No entanto, é preciso recordar que as peças de Sêneca, como afirmam alguns estudiosos, teriam sido escritas para leituras, como acrescenta Lohner (2009, p. 8), o que acarreta uma nova disposição e outras soluções cênicas:

O abandono do teatro e a preferência pelas salas de recitação acarretaram, no texto teatral, menor consideração dos expedientes relativos ao espetáculo e, em contrapartida, maior do uso dos recursos da linguagem para retratar, no caso das tragédias, a patologia passional e seus efeitos externos e para dar brilho à argumentação retórica, fatores que garantiram a manutenção do interesse pelo gênero trágico e mesmo sua revivescência, especialmente nos círculos aristocráticos.

Dessa forma, deve-se mencionar, por exemplo, a diferença existente entre os dois coros das tragédias. No drama de Ésquilo, são os anciãos de Argos que se fazem presentes e o tempo todo revelam um desespero, reflexo da tensão da cidade pelas notícias da guerra. Por outro lado, na peça de Sêneca, são as mulheres argivas que dão voz ao pensamento social, inserindo ponderação em uma situação que já é escancarada desde os primeiros versos.

É interessante lembrar que o Agamêmnon de Ésquilo é a primeira parte de uma trilogia, da qual as outras duas tragédias são compostas por dois coros femininos, tanto Coéforas como Eumênides. Com exceção de Eumênides, que possui o coro formado pelas Erínias, personagens centrais da trama, tanto em Agamêmnon quanto em Coéforas os coros exercem pouca influência no desenrolar dos acontecimentos. Assim, na realidade, as tragédias apresentam dois coros que possuem unicamente a função de comentar os acontecimentos e explorar as ações das personagens centrais. O mesmo ocorre na peça de Sêneca, em que o coro não representa uma voz significativa nas ações das personagens, mas apenas trata de comentar os acontecimentos.

Entretanto, tanto em Ésquilo quanto em Sêneca, há dois cantos corais que compõem um importante paralelo, tratando-se respectivamente do hino a Zeus (Aes. Ag. 160-83) e da ode aos deuses (Sen. Ag. 310-407). De um lado, tem-se na obra de Ésquilo a exaltação do pai dos deuses e a glória de sua soberania, de outro, a ode de Sêneca evoca todo o Olimpo, ressaltando as qualidades dos deuses que auxiliam os homens nas dificuldades.

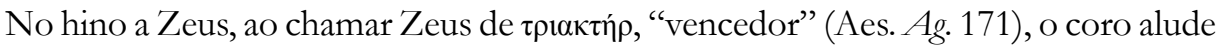
a sua vitória contra o pai Cronos que, por sua vez, havia destronado Urano. De acordo com Athanassakis (2004, p. 47), esses passos mostram duas entidades que foram sacrificadas por 
mulheres em favor de um novo reinado. Logo, é possível pensar que a remissão às origens de Zeus não seja tão gratuita, mas faça também uma referência ao próprio Agamêmnon, detentor do poder de Argos e que, em breve, seria um governante caído diante do poder de uma mulher.

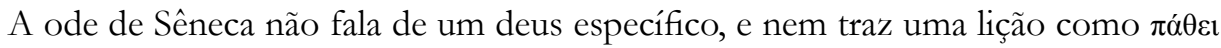
$\mu \alpha \dot{\theta} \theta \varsigma_{\text {, }}$ "O aprendizado pelo sofrimento", mas, conforme afirma Lloyd-Jones (1983, p. 87), as lições transmitidas por Ésquilo evidenciam que o preceito não está necessariamente relacionado ao próprio autor do ato, mas seria uma espécie de ensinamento universal da justiça divina como prova de que, em algum momento, algum membro de uma família envolvida em uma transgressão poderia sofrer as consequências. Reporta-se, assim, a um comedimento do homem em relação ao pai dos deuses, exatamente o mesmo tipo de medida adotada por Sêneca, com seu Júpiter, em um crescente para chegar à seguinte conclusão:

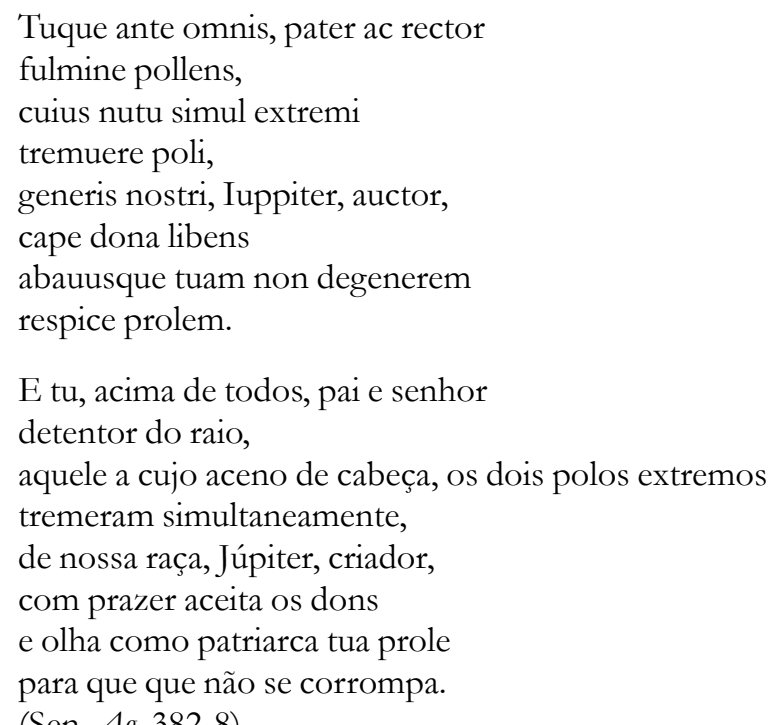
(Sen. Ag. 382-8)

Depois de lidar com algumas questões do coro, alguns outros aspectos estruturais também merecem atenção. Não passa despercebida, por exemplo, a inclusão do espectro de Tiestes no prólogo da tragédia de Sêneca. No entanto, não se trata de uma inovação senequiana, pois Ésquilo, em Persas (472 a.C.), já havia inserido o fantasma de Dario para maior efeito dramático. Sendo assim, a presença de Tiestes apenas confirma uma tendência da tragédia de evocar entidades que não pertençam ao mundo terreno e são detentoras de informações universais.

Todavia, o arauto presente na peça de Ésquilo também é um personagem que, por sua condição de vigia e atento às informações externas ao palácio, detém uma superioridade em relação às outras personagens. Assim, não é para menos que, tanto em uma tragédia quanto na outra, ambas as figuras sejam detentoras das angústias da espera para a concretização dos acontecimentos vindouros: 


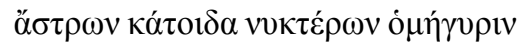

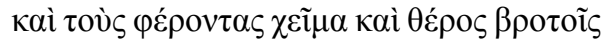

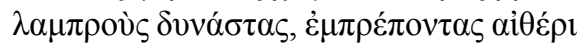

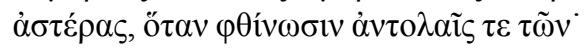

Conheci muito bem a companhia dos astros da noite e o verão e o inverno deslocando os focos luzentes para os homens, distinguindo as estrelas no céu, sempre que se deitam ou levantam.

(Aes. Ag. 4-7)

Sed cur repente noctis aestiuae uices hiberna longa spatia producunt mora, aut quid cadentes detinet stellas polo? Phoebum moramur: redde iam mundo diem.

Mas por qual razão sem explicação noites de verão sucessivas e longos invernos duram muito tempo, o que sustenta no polo as estrelas que caem? Detenhamos Febo. Devolve o dia ao mundo. (Sen. Ag. 52-6)

Assim como na tragédia de Ésquilo, o primeiro ato em Sêneca torna-se emblemático da necessidade de situar o espectador na trama. Todavia, diferentemente do que acontece em Ésquilo, a presença da figura de Egisto quebra uma expectativa da narrativa, visto que a própria rainha, desde sua primeira aparição, deixa claras as suas intenções em relação ao rei. Tal inserção, que representa outro fôlego para a narrativa é, por sua vez, causada por um efeito reverso em Ésquilo: a dissimulação de Clitemnestra. Embora, em uma tragédia, a rainha explicite seus planos e, em outra, ela questione a validade do ato, comparando sua união a Egisto com a vinda de Cassandra, a dissimulação ou transparência acabam por colocar as personagens em um mesmo patamar, discutindo a posição feminina diante do marido que governa:

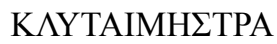

$[\ldots]$

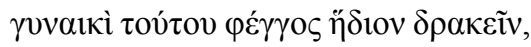

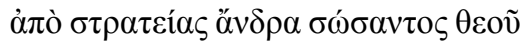

$\pi \hat{\jmath} \lambda \alpha \varsigma \dot{\alpha} \nu 0 \tilde{o} \xi \alpha 1 ;[\ldots]$

\section{CLITEMNESTRA}

$[\cdots]$

À mulher é doce ver a glória do marido, depois da expedição e abrir as portas ao homem quando salvo pelo deus? [...]

(Aes. Ag. 602-4)
} 


\section{CLYTEMESTRA}

nec coniugem hoc respicere nec dominam decet.

lex alia solio est, alia priuato in toro.

Quid, quod seueras ferre me leges uiro

non patitur animus turpis admissi memor?

\section{CLITEMNESTRA}

Nem à cônjuge nem à senhora é apropriado olhar para trás.

Há uma lei para o trono, há outra para o leito particular.

E por que meu orgulho, consciente da falta que infligi,

não suporta que eu imponha leis rígidas a meu marido?

(Sen. Ag. 263-6)

A despeito de que a tragédia de Ésquilo apresente uma Clitemnestra dissimulada, o que as passagens mostram é que elas estão em consonância com a discussão sobre a posição da mulher diante do retorno do marido. Se por um lado, em Ésquilo, a rainha fala sobre sua função diante do homem que volta da guerra, em Sêneca, por sua vez, ela questiona seu papel e hesita em aceitar o destino de Agamêmnon. O interessante na passagem reside no fato de que, por mais que façam uso de argumentos semelhantes, os dois autores delineiam suas Clitemnestras de formas diferentes, pois em Ésquilo evidencia-se o caráter vingativo da esposa de Agamêmnon, enquanto em Sêneca, conhece-se uma mulher que relativiza, inclusive, a chegada da concubina.

O terceiro ato da tragédia de Sêneca apresenta Euríbates dialogando com Clitemnestra. Mesmo não nomeado, o que era comum na tragédia de Ésquilo, o mensageiro também se apresenta à rainha com notícias da guerra. Nesse trecho, Lohner (2009, p. 183) afirmará, categoricamente, que as fontes de Sêneca teriam sido autores posteriores a Ésquilo, visto que o heleno não narra a tempestade ${ }^{10}$ que assolou a tropa no retorno para a casa. Entretanto, vale ressaltar que há dois aspectos que aproximam as duas passagens: primeiramente, um questionamento sobre o destino de Menelau:

\section{XOPO $\Sigma$}

$[\ldots]$

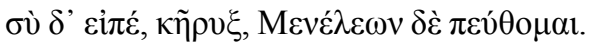

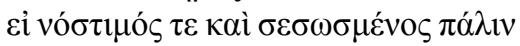

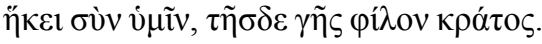

CORO

[...

Diz, mensageiro, conte-me sobre Menelau.

Se ele está salvo, retornou e

está convosco, desta terra o amado governante.

(Aes. Ag. 617-9)

\footnotetext{
${ }^{10}$ Aqui é importante notar que, embora Ésquilo não narre a tempestade, ela pertencia ao mito e já havia sido citada em outra tragédia anterior a Sêneca, dessa vez de Eurípides. Em Helena (412 a.C.), entre os versos 125 e 130, o diálogo entre Teucro e Helena remete às tempestades em alto-mar.
} 


\section{CLYTEMESTRA \\ $[\ldots]$ \\ tu pande vivat coniugis frater mei \\ et pande teneat quas soror sedes mea. \\ CLITEMNESTRA \\ $[\ldots]$ \\ Tu, revela se o irmão de meu marido vive \\ e revela onde minha irmã reside.}

(Sen. Ag. 404-5)

Na tragédia de Ésquilo, é o coro que cumpre o papel de questionar sobre a vida de Menelau, o que, em Sêneca, torna-se justificado por uma preocupação de Clitemnestra com o destino de sua irmã Helena. No entanto, o que chama a atenção nos dois passos é a importância dada à notícia sobre o irmão de Agamêmnon em meio a informações que tendem a se concentrar na volta do consorte de Argos. Trata-se de um mesmo argumento utilizado pelos dois autores para, na realidade, falarem sobre as naus que se perderam no mar.

Todavia, há ainda um paralelismo maior, que requer atenção, nos diálogos dos mensageiros nas duas obras. Trata-se de um mesmo comportamento de retidão que faz com que eles acabem por realizar um mesmo discurso:

\section{KHPY $\Xi$}

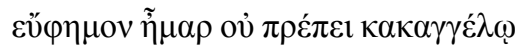

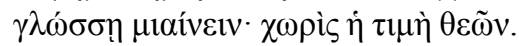

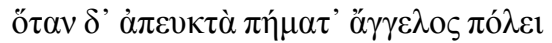

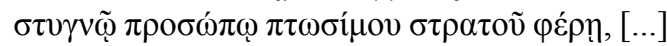

\section{MENSAGEIRO}

Não é auspicioso em dia propício declarar notícia ruim. Cada honra aos deuses em partes.

Sempre que o mensageiro traz o semblante sombrio para a cidade com notícias ruins do exército caído, [...]

(Aes. Ag. 636-9)

\section{EVRYBATES}

Acerba fatu poscis, infaustum iubes

miscere laeto nuntium, refugit loqui

mens aegra tantis atque inhorrescit malis.

\section{EURÍBATES}

Pedes que eu fale de coisas amargas, mandas-me misturar notícia infeliz a uma feliz. Mas recusa minha mente perturbada a falar e toda estremece de tantas desgraças.

(Sen. Ag. 416-8) 
Não é só a integridade que faz os mensageiros serem polidos em relação a seus discursos, mas uma tendência greco-romana de não alimentar o mau-agouro através do cuidado com o que se profere (à $\gamma \gamma \hat{\varepsilon} \lambda \lambda \omega$, 'declarar, portar uma notícia', que é apresentado

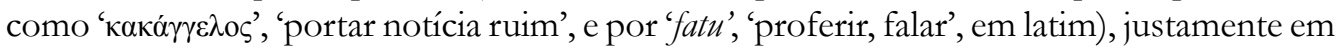
um momento de notícias felizes; porém, mais do que isso, é o resultado de uma emulação de discurso pelas palavras de um personagem nomeado, papel este que, em Ésquilo, possui grande importância para a peripécia narrativa.

De acordo com Barret (2002, p. 13), além da função de informar ou advertir sobre algum acontecimento, o mensageiro traz consigo uma espécie de quebra no ritmo da narrativa, e sua linguagem é marcadamente diferente da linguagem dos outros personagens. Em Agamêmnon de Ésquilo, especificamente, um mensageiro não nomeado representa uma figura que, muito provavelmente, não era própria do mito e teria sido inserida pelo autor com a função de transmitir informações que revertam ou confirmem o status quo.

A presença de Cassandra em ambas as tragédias também é uma intrigante inserção dos dois autores, cuja análise revela construções bem próximas e com um objetivo comum: aumentar a tensão dramática, visto que a profetisa é quem consegue transitar para além de onde os personagens ordinários conseguem ir. O transe que ocorre nas duas tragédias leva a concubina a trazer à tona inúmeras referências selvagens, mesclando metáforas de animais aos atos proferidos pelos homens. Dessa forma, pode-se apreender passagens como:

\section{$\mathrm{KA} \Sigma \Sigma \mathrm{AN} \triangle \mathrm{PA}$}

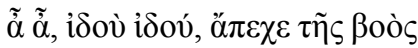

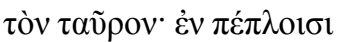

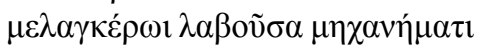

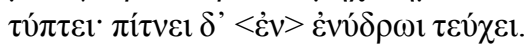

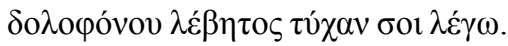

\section{CASSANDRA}

Ai, ai, afasta o touro

da vaca! No tapete

os chifres negros segurando pelo manto

abate. Afunda no reservatório envolto em água

Narro a sorte do ardil na banheira.

(Aes. Ag. 1125-9)

\section{CASSANDRA}

$[\ldots]$

At ille, ut altis hispidus siluis aper

cum casse uinctus temptat egressus tamen

artatque motu uincla et in cassum furit, [...] 


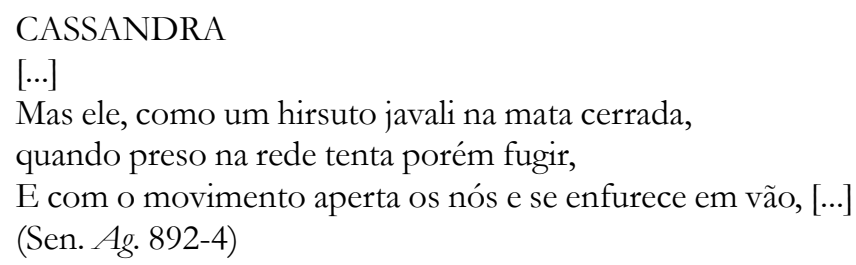

Ao longo dos séculos, a literatura mostrou que a figura animal sempre foi uma forma convincente de metáfora. A partir de Homero, a tradição ocidental registra uma quantidade infindável de relações entre homens e animais. Acerca desse assunto, Durand (2002, p.70) faz a seguinte asserção:

O animal apresenta-se como um abstrato espontâneo, o objeto de uma assimilação simbólica, como mostra a universalidade e a pluralidade da sua presença tanto numa consciência civilizada como na mentalidade primitiva. A Linguística comparada notou também, desde há muito tempo, que a repartição de substantivos se faz primitivamente segundo as categorias do animado e do inanimado. O Bestiário, portanto, parece solidamente instalado na língua, na mentalidade coletiva e na fantasia individual.

Sendo assim, pode-se pensar que o ato criminoso é um reflexo de sensações primitivas, de um afastamento da consciência racional. Obviamente, é preciso levar em consideração que o transe frenético, próprio do caráter profético e oracular, é registrado desde a Antiguidade, principalmente aqueles ligados ao culto a Dioniso (Baco), como um devaneio em que o homem perde sua capacidade de discernimento e o próprio controle sobre a razão. No entanto, é curioso pensar que, especificamente nesse momento das duas tragédias, os autores façam uso de metáforas animais para exporem os vaticínios de Cassandra, e muito embora as figuras sejam diferentes (boi e vaca em Ésquilo, javali em Sêneca), a ideia de uma presa fácil, de um animal encurralado, demonstra a semelhança dos procedimentos dos autores.

Por fim, os dois dramas terminam de formas bem diferentes, mas com sutilezas que os aproximam. Na tragédia de Ésquilo, por se tratar de uma trilogia da qual Agamêmnon é a primeira parte, a personagem de Electra só aparecerá em Coéforas, tragédia na qual a irmã de Orestes é a mulher amargurada pelo crime da mãe e escrava no próprio palácio. Em Sêneca, embora a filha de Agamêmnon trate logo de mandar o irmão embora, mostrando sua atitude e descontentamento com os atos da mãe, o que a aproxima da figura construída por Ésquilo, sua presença em cena parece apenas reforçar a motivação destruidora de Clitemnestra que, após aceitar seu destino, torna-se uma voraz predadora de seus inimigos, não poupando nem mesmo os próprios filhos.

No entanto, apaziguada por Egisto - o que chama a atenção, haja vista que ele demonstra uma piedade que não existiu em toda a tragédia -, Clitemnestra é convencida pelo amante a tratar a filha como cativa em seu próprio lar. A esse respeito, não se pode negar a 
força da personagem de Electra que, certamente, Sêneca conhecia pela tradição. Ainda na tragédia ática, os três tragediógrafos lidaram com essa figura contraditória, marcada pela revolta e desejo de vingança em nome do pai.

Como recorda Conacher (1967, p. 204), Eurípides e Sófocles ter-se-iam empenhado na construção dessa personagem, devido à importância que Electra assume na tradição de condutora da vingança contra a mãe:

Eurípides, como Sófocles e por razões semelhantes, deve ter certeza de que a maior atenção está centrada apenas em Electra. Em uma peça onde a caracterização individual e a motivação são fundamentais, apenas um dos dois filhos matricidas pode ser de real importância; o que vemos ou ouvimos do outro deve, de alguma forma, contribuir para a nossa compreensão do caráter central.

Dessa forma, Electra não é apresentada de forma gratuita por Sêneca, há uma razão para que a personagem esteja ali naquele momento, pois é ela, no contexto mítico, que domina a situação. O diálogo final entre Cassandra e Clitemnestra é o ensejo para o ouvinte compreender que aquela narrativa não findava ali:

\section{CLYTEMESTRA}

Furiosa, morere.

CASSANDRA

Veniet et uobis furor.

\section{CLITEMNESTRA}

Morre, sua louca!

CASSANDRA

A vós também virá uma loucura.

(Sen. Ag. 1011-2)

O jogo criado por Sêneca com as palavras furore furiosus (traduzidas, respectivamente, como loucura e louca) remetem justamente às Furiae (Fúrias), entidades punidoras dos crimes consanguíneos e que se apresentam como fundamentais nas tragédias seguintes da Oresteia. Além disso, é impossível deixar de registrar a fala do mensageiro, cuja presença em Ésquilo parece ecoar no drama senequiano:

\section{KHPY $\Xi[\ldots]$}

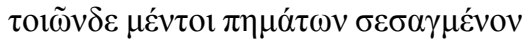

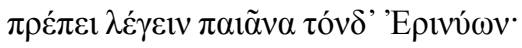

\section{MENSAGEIRO}

Então, oprimido por estas calamidades

convém que ele recite este peã das Fúrias.

(Aes. Ag. 644-5) 


\section{Conclusão}

O presente artigo procurou propor alguns apontamentos a fim de mostrar que, apesar de a tradição não chegar a uma conclusão efetiva sobre as fontes que propiciaram a Sêneca compor sua tragédia sobre o fim da vida de Agamêmnon, não são poucos os indícios que podem ser fornecidos sobre uma possível emulação senequiana da tragédia Agamêmnon de Ésquilo.

Ao discorrer sobre as duas tragédias com a brevidade que este artigo exige, a intenção foi justamente demonstrar algumas das diferentes estruturas que compõem os dramas, apontar os aspectos que as aproximam ou as distanciam e, assim, poder discutir as questões que são pertinentes ao conceito de aemulatio. A esse respeito, vale ressaltar que, embora sejam vários os autores que citam o uso de imitatio e aemulatio como reflexões do trabalho de composição literária, trata-se de noções que são exploradas pela tradição com enfoques diferentes, quer seja pela discussão acerca dos modelos literários, quer seja por análises muito específicas do uso dos conceitos.

É por essa razão que, ao analisar alguns traços da emulação senequiana, cuidou-se de registrar elementos que, de fato, estabelecem uma relação entre os dois textos, não apenas apontando semelhanças na narrativa mítica, mas salientando personagens, símbolos e falas que também aproximam as duas obras. Sendo assim, convém salientar que a marca esquiliana permaneceu viva na tragédia do autor latino, o que significa que, para Sêneca, por via direta ou indireta, tendo ou não Ésquilo como sua fonte primária de inspiração, a própria tradição já havia realizado esse feito que ele faz ecoar em seu Agamêmnon.

\section{REFERÊNCIAS}

ACHCAR, F. Lirica e lugar-comum: alguns temas de Horácio e sua presença em português. São Paulo: USP, 1994.

AÉLION, R. Euripide, héritier d'Eschyle. Paris: Les Belles Lettres, 1983. t. 1-2.

AESCHYLI Septem quae supersunt tragoedias. Edidit Denys Page. New York: Oxford University Press, 1972.

ARISTÓTELES. Poética. Prefácio de Maria Helena da Rocha Pereira. Tradução e notas de Ana Maria Valente. 4 ed. Lisboa: Calouste Gulbenkian, 2011.

ARISTÓTELES; HORÁCIO; LONGINO. A poética clássica. Introd. Roberto de Oliveira Brandão. Trad. grego e latim Jaime Bruna. 12 ed. São Paulo: Cultrix, 2005.

ARISTOTELIS De Arte Poetica Liber. Edidit R. Kassel. England: Oxford, 1968.

BARRET, J. Staged narrative: poetics and the messenger in Greek tragedy. Berkeley: University of California Press, 2002.

BEARE, W. The Roman Stage. 3rd ed. London: Methuen, 1968. 
BRANDÃO, J. de S. Mitologia Grega. 22 ed. Petrópolis: Vozes, 2010. v. 1.

BURKERT, W. Antigos cultos de mistério. Tradução de D. Bottman. São Paulo: EDUSP, 1991.

CARDOSO, Z. de A. Estudos sobre as tragédias de Sêneca. São Paulo: Alameda, 2005.

CICERO. M. Tullius Cicero: Tusculanae Disputationes. Edited by M. Pohlenz. Leipzig: Teubner, 1918.

CHANTRAINE, P. Dictionnaire étymologique de la langue grecque. Histoire des mots. Paris: Klincksieck, 2009.

COMPAGNON, A. O demônio da teoria: literatura e senso comum. Tradução de Cleonice Paes Barreto Mourão e Consuelo Fortes Santiago. Belo Horizonte: UFMG, 2006.

CONACHER, D. J. Euripidean drama: myth, theme and structure. Toronto: University of Toronto Press, 1967.

DOWDEN, K. Os usos da mitologia grega. Tradução de Cid Knipel Moreira. Campinas: Papirus, 1994.

DURAND, G. As estruturas antropológicas do imaginário. São Paulo: Martins Fontes, 2002.

ERASMO, M. Roman tragedy: theatre and theatricality. Austin: University of Texas Press, 2004.

ERNOUT, A; MEILLET, A. Dictionnaire étymologique de la langue latine. Paris: Klincksieck, 2001.

ÉSQUILO. Agamêmnon. Introdução, tradução e notas de Trajano Vieira. São Paulo: Perspectiva, 2007.

ÉSQUILO. Agamêmnon. Trad. de Jaa Torrano. São Paulo: Iluminuras, 2004.

EURIPIDIS Fabulae. Edidit J. Diggle. New York: Oxford University Press, 1994. t. 3.

FURLAN, M. Brevíssima história da teoria da tradução no Ocidente. I - Os romanos. Cadernos de Tradução, v. 2, n. 8, p. 11-28, 2001.

GLARE, P. G. W. Oxford Dictionary of Latin. New York: Oxford at the Clarendon Press, 1986.

HERMANN, L. Le théâtre de Sénèque. Paris: Les Belles Lettres, 1924.

HESIOD. Theogony, Works and Days, Shield. 2nd ed. Translation, introduction and notes by Apostolos N. Athanassakis. Baltimore: The John Hopkins University Press, 2004.

HESÍODO. Teogonia. A origem dos deuses. Estudo e tradução de Jaa Torrano. São Paulo: Iluminuras, 1991.

LIDDELL, H. G; SCOT'T, R. A Greek-English Lexicon. Oxford: Clarendon Press, 1996.

LLOYD-JONES, H. The justice of Zeus. 2nd ed. California: University of California Press, 1983. 
LONGINUS. Longinus, On the Sublime. Edited by William Rhys Roberts. Cambridge: Cambridge University Press, 1907.

MARTINS, P. Literatura latina. Curitiba: Iesde Brasil, 2009.

MOREAU, A. Eschyle: la violence et le chaos. Paris: Les Belles Lettres, 1985.

QUINTILIAN. The Instituto Oratoria of Quintilian. With an English translation. Edited by Harold Edgeworth Butler. Cambridge: Harvard University Press; London: William Heinemann, 1922.

RODON, E. Parole d'ira e parole d'amore nei personaggi femminili delle tragedie di Seneca. Dioniso, v. 52, p. 47-54, 1981.

SENECA. Agamemnon. Cambridge Classical texts and commentaries by R. J. Tarrant. Cambdridge: Cambridge University Press, 1976.

SÊNECA. Agamêmnon. Introdução, tradução e notas de José Eduardo dos Santos Lohner. São Paulo: Globo, 2009.

SENECA. L. Annaei Senecae tragoediae. Recognouit Otto Zwierlein. New York: Oxford University Press, 1999.

SERRANO, D. de P. Caracterización de Clitemnestra y Agamenón de Esquilo a Séneca. Myrtia, v. 18, 2003, p. 105-27.

STAR, C. Euripides and Senecan drama. In: MCCLURE, L. K. (ed.). A companion to Euripides. London: Wiley-Blackwell, 2017.

VEYNE, P. Seneca: the life of a stoic. Translated by David Sullivan. New York: Routledge, 2003.

VICKERS, B. Towards Greek tragedy. Drama, myth, society. New York: Longman, 1973.

VIEIRA, B. G. Agamêmnon. Introdução, tradução e notas de José Eduardo dos Santos Lohner. São Paulo: Globo, 2009.

VIEIRA, B. G. Cícero e seu projeto tradutório. Calípe: Presença Clássica, v. 15, p. 23-35, 2006. 
